\title{
Amor ao futuro
}

\author{
RUI PINA COELHO
}

Às vezes, para ajudar um coração amigo a sarar, diz-se que da perda pode resultar um recomeço. Mas, em boa verdade, parece-me, da perda raramente sobra muito mais do que o vazio do luto. $\mathrm{O}$ resto são coisas que, às vezes, o tempo cura. Às vezes. Nem sempre. Servem estas palavras lamentosas para evocar o nosso companheiro e amigo Juan Antonio Hormigón (1943-2019), falecido em Abril. Director da revista espanhola $A D E$, da Asociación de Directores de Escena, que dirigia desde a sua fundação, foi um impenitente intelectual de todas as coisas do teatro, deixando uma marca indelével no teatro europeu, nos muitos textos que deixou, nos livros que editou, nos alunos e actores que apoiou, nos espectáculos que discutiu... Mas lembramo-lo também pela veneranda bonomia e pela sagacidade com que enchia uma sala. Vai fazer-nos falta.

Este número da Sinais de Cena abre com um Dossiê Temático dedicado à Prática como Investigação. Na chamada para artigos, declarávamos:

\begin{abstract}
A Prática como Investigação - chapéu terminológico utilizado para nomear o tipo de pesquisas baseadas e/ou apresentadas sob a forma de prática(s) artística(s) - conta com um percurso consolidado de experiências e o reconhecimento crescente no campo da investigação em artes. Encontra-se, contudo, ainda num estado de procura de um vocabulário, metodologias e modos próprios de articulação institucional, em particular na esfera das artes performativas, cujas características exigem uma reconfiguração das formas canónicas de investigação e produção de conhecimento.

Neste Dossiê Temático visa-se perscrutar os diferentes modos como as teorias, discursos críticos e exemplos práticos têm articulado os desafios inerentes à Prática como Investigação em artes performativas face aos actuais modelos de produção e legitimação do conhecimento.
\end{abstract}

Sob a direcção de Paula Caspão e Gustavo Vicente, dois dos investigadores que mais labor têm dedicado entre nós a estas questões, este dossiê constitui-se como um óptimo ponto de entrada para uma maior complexificação do tema, desbravando bibliografia e, sobretudo, convocando diversas práticas artísticas que foram sabendo fazer esboroar a já bafienta separação entre a teoria e a prática. 
A dimensão ensaística deste número da $S d C$ - nos Estudos Aplicadosprolonga esta atitude. Nos onze ensaios que constituem esta secção, estão patentes várias das disciplinas e dos instrumentos de análise que têm vindo a fazer dos estudos de teatro e da performance um vibrante caleidoscópio de pensamento. Assim, são chamados os métodos da historiografia do teatro, da crítica de dança e de teatro, da exegese dramatúrgica ou da museologia para tratar de um corpus dramatúrgico, de espectáculos de dança, de teatro ou da arte da performance, mas também para tratar de questões relacionadas com metodologias de trabalho, actores ou com a impressiva memória que os espectáculos deixam nos espectadores. Uma amostra que bem demonstra a extraordinária potência deste campo de estudos para tratar das coisas do mundo.

Neste número, que balança entre olhar para o passado e para o futuro, revelamos algum do Portefólio de José Marques (1924-2012), que, através da sua câmara, enquanto se inventava «fotógrafo de cena», foi registando das décadas mais vibrantes da história do teatro recente em Portugal: do movimento de teatro experimental dos anos 60 ao estabelecimento do teatro independente nos anos 70. Um trabalho mais uma vez documentado e apresentado por Filipe Figueiredo e Paula Gomes Magalhães.

Apontando pungentemente para o futuro está a entrevista que se regista em Primeira Pessoa ao actor e encenador Pedro Gil. Nesta conversa revela-se um criador em permanente autocrítica e desejo de experimentação, conhecedor, como poucos, do intricado tecido da criação teatral em Portugal. Numa entrevista a que se deverá voltar muitas vezes de modo a melhor irmos entendendo as suas razões artísticas, Pedro Gil perscruta os seus modos de fazer e de pensar, provando - se acaso fosse necessário - que não há distância entre a teoria e a prática.

Em Passos em Volta e Leituras, vários críticos e investigadores de teatro portugueses deixam registo de alguns dos trabalhos que marcaram o ano teatral. Assim, o trabalho de Sónia Baptista, Joclécio Azevedo, Maria Duarte, Sílvia Figueiredo e João Rodrigues, Teatro Praga, Inês Barahona e Miguel Fragata, entre outros, é pensado e discutido, ampliando criticamente a sua zona de impacto.

É por acreditarmos que mesmo na perda é preciso não baixar os braços, que entre o luto e a luta muito há a fazer, que vamos insistindo nesta aventura a que vamos chamando Sinais de Cena, balançando entre o adeus ao passado e o amor ao futuro. 